\title{
Shakespeare and the fortunes of war and memory
}

\section{Andrew Hiscock}

Christophe Hausermann (ed.)

\section{(2) OpenEdition}

\section{Journals}

Electronic version

URL: http://journals.openedition.org/shakespeare/1913

DOI: 10.4000/shakespeare.1913

ISSN: 2271-6424

\section{Publisher}

Société Française Shakespeare

Printed version

Date of publication: 1 April 2013

Number of pages: 11-26

ISBN: 2-9521475-9-0

\section{Electronic reference}

Andrew Hiscock, "Shakespeare and the fortunes of war and memory ", Actes des congrès de la Société française Shakespeare [Online], 30 | 2013, Online since 03 April 2013, connection on 06 May 2019.

URL : http://journals.openedition.org/shakespeare/1913; DOI : 10.4000/shakespeare.1913 


\section{Shakespeare et la mémoire}

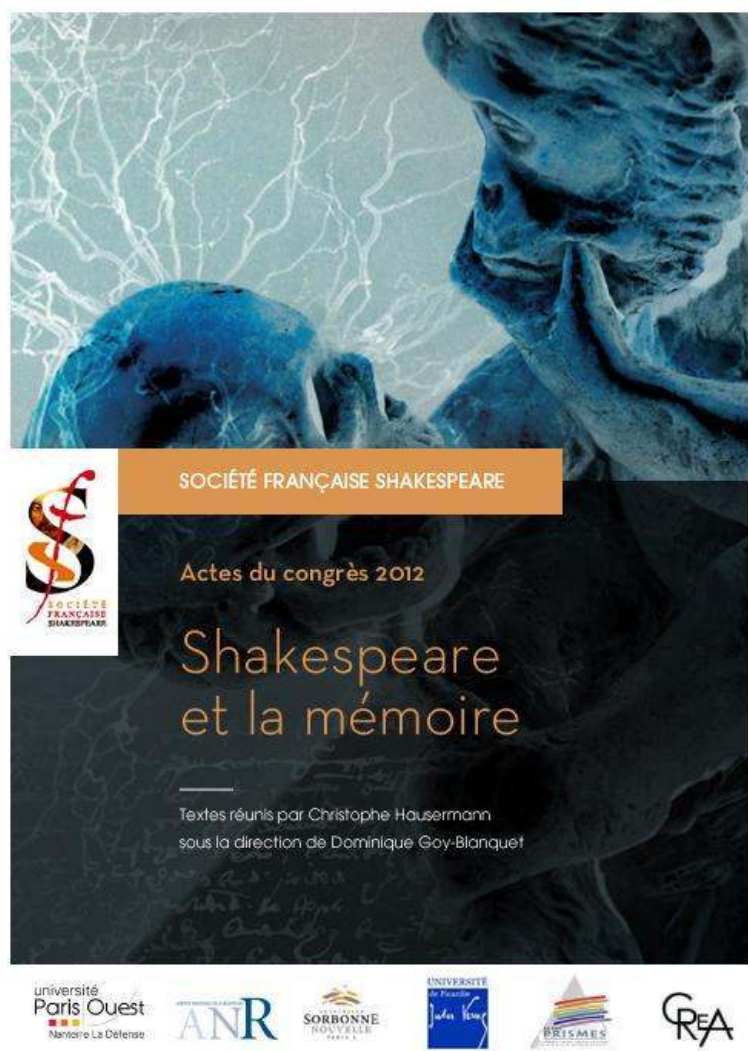

actes du Congrès

organisé par la

SOCIÉTÉ FRANÇAISE SHAKESPEARE

les 22, 23 et 24 mars 2012

textes réunis par

Christophe HAUSERMANN

sous la direction de

Dominique GoY-BLANQUET 


\section{COUVERTURE}

d'après l'affiche de Claire Colombet

conception graphique et logo

Pierre Kapitaniak

mise en page et corrections

Christophe Hausermann

(C) 2012 Société Française Shakespeare

Institut du Monde Anglophone

Université de Paris III - Sorbonne Nouvelle

5 rue de l'École de Médecine 75006 Paris

www.societefrancaiseshakespeare.org

Tous droits de traduction, de reproduction et d'adaptation réservés pour tous les pays 


\title{
SHAKESPEARE AND THE FORTUNES OF WAR AND MEMORY
}

\author{
Andrew Hiscock
}

\begin{abstract}
Cet article souligne l'importance de la mémoire dans les pièces historiques de Shakespeare, qui datent des années 1590, et leur participation aux débats contemporains sur la militarisation de la société au cours du règne d'Élisabeth lère. Dans plusieurs de ces pièces historiques, les belligérants issus de l'aristocratie essaient de transformer le passé et l'avenir de la nation. Dans ce contexte, la mémoire devient inévitablement une ressource stratégique permettant d'aboutir à un changement politique. S'appuyant sur les deux tétralogies historiques de Shakespeare, cet article entend démontrer comment la mémoire peut engendrer la violence, ou la contrer, dans des sociétés politiquement fragiles.
\end{abstract}

This article focuses upon the importance of memory in Shakespeare's history plays of the 1590s and the ways in which these plays may link with contemporary debates concerning militarised society in the reign of Elizabeth I. Many of these history plays present the attempts of warring aristocrats to reshape the past of the nation and to lay claim to its future. Inevitably, in this context, memory becomes a key resource with which to consolidate a commitment to political change. Drawing upon examples from the two tetralogies of history plays, this discussion explores how violence may be engendered or resisted in fragile political societies with the resources of memory.

Memory is a primary and fundamental faculty, without which none other can work; the cement, the bitumen, the matrix in which the other faculties are imbedded; or it is the thread on which the beads of man are strung, making the personal identity which is necessary to moral action. Without it all life and thought were an unrelated succession. As gravity holds matter from flying off into space, so memory gives stability to knowledge; it is the cohesion which keeps things from falling into a lump, or flowing in waves. ${ }^{1}$

$\mathrm{R}$ alph Waldo Emerson's contention, taken here from his collection The Natural History of the Intellect and Other Papers, that memory operates like "the cement, the bitumen, the matrix in which other faculties are imbedded" may be seen to hold particular relevance for a consideration of the complex and evolving understandings of a faculty which comes under increasing scrutiny in Shakespeare's History plays. This pervasive idea that the faculty might bind and loose the organising principles of human society and subjectivity meets with repeated interrogation as the first tetralogy, for example, unfolds. These plays, which rehearse in a highly selective and creative manner the reigns of Henry VI and Richard III in fifteenth-

1 "Memory", in Ralph Waldo Emerson, The Natural History of the Intellect and Other Papers, Boston, Houghton Mifflin, 1899, p. 63. 
century England, constantly urge us to examine and to re-examine the status and functions of memory through the prism of "That ever living man of memory, / Henry the Fifth" (1 Henry VI, IV.iii.51-52), ${ }^{2}$ a figure who comes in the minds of many to symbolise an age of martial glory which is now exceeding the grasp of the English nation.

Indeed, the more we penetrate the fractious dramatic environments of Shakespeare's early History plays the more we are asked to attend to the degree to which human communities construct mythologies of belonging and identity through the seemingly infinite plastic resource of re-membering collective and individual pasts. At the beginning of 1 Henry VI, for example, the Bishop of Winchester recalls for his auditors the sovereignty of the late king in superlative terms normally reserved for the potentates of Scripture: "Unto the French, the dreadful judgement-day / / So dreadful will not be as was his sight. / The battles of the Lord of Hosts he fought" (1 Henry VI, I.i.2931). This towering figure of the dead Lancastrian king is in fact deployed again and again in this and succeeding dramatic narratives as the axis along which to judge any aspiration towards political arete

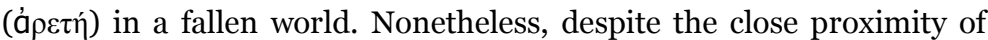
Henry V's lifeless body as 1 Henry VI opens, it soon becomes apparent that Winchester's richly ornamented eulogy to Harry and his deathless memory can do little to resist the destructive powers of time or to instil confidence that a new age of glory awaits the English nation under the governance of a boy king. In this period of collective mourning, spectators on- and off-stage are compelled to bear witness to the dispiriting spectacle of the collapse of human communion and political leadership among the nation's elite - an elite which will henceforth be exercised predominantly by the irresistible pleasures of the vendetta. Indeed, both for the English warrior lords and theatre audiences, the spectral figure of Henry $\mathrm{V}$ remains in narrative (rather than historical) terms the measure with which to appreciate the declining fortunes of his former subjects and the parlous situation in which his inexperienced son repeatedly places the receding space of his nation. Furthermore, given over to such an incessant regime of acrimonious division and militarised combat, it is perhaps unsurprising that this

\footnotetext{
${ }^{2}$ All references to Shakespeare's plays are from The Norton Shakespeare, based on the Oxford Edition, eds. Stephen Greenblatt, Walter Cohen, Jean E. Howard, Katharine Eisaman Maus, New York/London, W. W. Norton \& Co., 1997.
} 
cultural environment engenders its own specific or stunted strains of identity and history amongst its inhabitants.

In order to fully apprehend the blighted fate of the English nation, unusually for Shakespeare's History plays, 1 Henry VI insists that we adopt a bi-focal lens: we are drawn to scrutinise the conditions of human existence brutalised by war in an international context. In the event, it matters little on which side of the Channel the dramatic narrative unfolds, the greenhorn king finds himself repeatedly in hostile territory - territory in which Lancastrian sovereignty and the geographical integrity of English imperial possessions remain under constant threat. Henry VI himself reminds his companions, "my lords, remember where we are / In France, amongst a fickle wavering nation" (Iv.i.137-8). Indeed, the Henry VI plays fashion a sequence of alien, resistant, monstrous environments which may sustain "Pucelle or pucelle, Dauphin or dog-fish" (1 Henry VI, I.vii.85) and it becomes increasingly apparent that the young king is not the only one to negotiate difficulties in navigating through this changeful land of wavering allegiances and ceaseless brutality.

\section{Recession and succession}

One of the most striking ways in which Shakespeare's characters fashion their identities and the identities of others across the three Henry VI plays is through the deployment of a memorial relationship with the dead Lancastrian king. When Salisbury is killed in France, far from his native land, Talbot recalls that this was a man who "In thirteen battles [...] o'ercame". The fallen warlord also comes to emblematise a most precious link with a fleeting age of military achievement: "Henry the Fifth he first train'd to the wars" (1 Henry VI, I.vi.56-7). Subsequently, it even comes into the mind of the royal son, Henry VI, when he greets his premier warrior, Talbot, "I do remember how my father said / A stouter champion never handled sword" (III.viii.18-9). In Temps et récit, Paul Ricœur is at pains to stress the narrative demands of the human psyche and how again and again in our collective dealings, "Le temps devient temps humain dans la mesure où il est articulé de manière narrative". ${ }^{3}$ In Shakespeare's History plays from the 1590 s concerning the troubled reign of

3 Paul Ricœur, Temps et récit, tome I, Paris, Le Seuil, 1983, p. 17. 
Henry VI, the remorseless narratio of an absent patriarch not only places an insistent pressure upon the subsequent political fortunes of his abandoned realm, it also re-affirms an irrepressible desire widely in evidence across the stage community for the slaking of individual appetite through a collectively performed theatre of violence.

The recollection of Henry $\mathrm{V}$ is not the sole discourse of memory transactions in this dramatic environment. As the plays unfold, the evocations of King 'Harry' are called upon to speak to and to compete for their place against other histories, making a claim for powers of heroic intervention in the nation's life. In Rouen, for example, Talbot's mind is richly exercised by Plantagenet legacies: "in this late-betrayed town / Great Coeur-de-lion's heart was buried" (1 Henry VI, III.vi.4142), whereas later in 3 Henry VI, Oxford also urges his companions to recall this earlier line of Plantagenets: "great John of Gaunt, / Which did subdue the greatest part of Spain" (III.iii.80-1). In these dramatisations of fifteenth-century England re-presented for the Elizabethan stage, if the bloodthirsty patriciate at Henry VI's court regrets, or declares repeatedly that it regrets, the premature loss of the hero of Agincourt, this in no way stifles equally potent narratives from Scripture and Antiquity from entering the national consciousness to striking effect. Confronted with the triumphing English armies in 1 Henry VI, Alençon is compelled to recognize the authority of the history-makers, the chroniclers, who have hitherto limned the character of France's antagonists: "Froissart, a countryman of ours, records, / England all Olivers and Rowlands bred"; yet now these forces travelling from a distant land appear on the battlefield like the heroes described in Holy Writ: "none but Samsons and Goliases" (I.iii.8-9,12). Elsewhere, in the presence of Richard Plantagenet, the declining Mortimer (a longstanding victim of Lancastrian sovereignty or emnity) attempts to recover a remnant of his former legitimacy and casts himself as "Nestor-like" (1 Henry VI, II.v.7), whereas York is figured as Ajax Telamonius (2 Henry VI, v.i.26) and Margaret of Anjou as Queen Dido (2 Henry VI, III.ii.117). The constant iteration of all these competing narratives of heroism bequeathed from the past not only demonstrates the multifarious exemplae which this dramatic community may deploy in the assertion of its many and various political ambitions, but how remote these heroic agents now appear in the midst of the grim realities of a failed state. 
Not only does the highly selective retrieval of pasts for present consumption characterise political life in fifteenth-century England in the Henry VI plays, these revered narratives are also seen to bring with them a panoply of ceremonial and ethical obligations. As we have seen, Part I opens at a decisive moment of national parturition: as court gives way to lamentation at the funeral rites of Henry V, Bedford incants, "Hung be the heavens with black! Yield day to night!" (I.i.1). Interestingly, as this performance of national mourning for eyes onand off-stage proceeds, the dramatic emphasis is not primarily upon the tottering government of Henry VI nor upon the warrior cabales that are forming at the heart of the London court. Rather, both the aural and visual effects being conjured up in the scene focus upon the acute need of the community to invest in and renew itself through the power of memory. In this context, we may be reminded of Mikhail Bakhtin's contention that

Greatness always makes itself known only to descendents, for whom such a quality is always located in the past (it turns into a distanced image); it has become an object of memory and not a living object that one can see and touch [...] In the world of memory a phenomenon exists in its own peculiar context, with its own special rules, subject to conditions quite different from those we meet in the world we see with our own eyes, the world of practice and familiar contact [...] Contemporaneity for its own sake (that is to say, a contemporaneity that makes no claim on future memory) is moulded in clay; contemporaneity for the future (for descendents) is moulded in marble or bronze. ${ }^{4}$

The perceived fixity of Henry V's achievement, extravagantly staged in material and rhetorical terms at the opening of 1 Henry VI, is thus placed in stark contrast to the changeful environment of military defeat and divided loyalties which are being spawned in a disaffected stagepresent. If, as we have seen, at the opening of 1 Henry VI Winchester impresses upon his auditors that the late king meted out government and justice to his people after the manner of an Old Testament patriarch ("a king blest of the King of Kings" (I.i.28), his sense of loss is shared by an ever growing number of those peers onstage who give way to lamentations regarding the parlous nature of the present regime and the failing military prowess of the nation's forces. Ultimately, the

\footnotetext{
${ }^{4}$ M. M. Bakhtin, "Epic and Novel. Toward a Methodology for the Study of the Novel", in The Dialogic Imagination: Four Essays, ed. Michael Holquist, trans. Caryl Emerson/Michael Holquist, Austin, Texas U.P., 2000, p. 18-19.
} 
shrouded body of the late king comes increasingly to act onstage as a most eloquent and forbidding magistrate upon the decaying political fortunes of the Lancastrian dynasty.

\section{Changing régimes of memory}

As the narratives of the Henry VI plays develop, the young and most errant king is branded with an ever expanding range of identities, some of which he willingly assumes himself. On his envoys' return from the French wars this beleaguered Lancastrian is determined to affirm his sovereignty by showcasing what he believes to be a guarantor of peace and a valuable trophy, Margaret of Anjou. If, with this alliance, Henry seeks vainly to foreclose any further contentious debate at his court and to placate his most unruly subjects, he is in fact only exploiting a familiar paradigm inherited from his father who returned to the island kingdom with a new spouse drawn from the ranks of his French adversaries, Catherine of Valois. However, even in that later Shakespearean play, audiences are not encouraged by any reassurance of lasting political settlement at the hands of a king who mistakes the exporting of war overseas for the exercise of government: "Is it possible dat I sould love de ennemi of France?” (Henry V, v.ii.163).

However, in 1 Henry VI, few on stage are minded to give credit to this lacklustre renewal of King Harry's deeds or to stifle their misgivings over the new king's policies of capitulation and withdrawal. The young Henry is greeted with a profoundly dispirited courtly environment after this "conquest". Indeed, Henry's uncle, the Duke of Gloucester proposes that, rather than triumphalism, the nation would do well to re-assume its customary mode of lamentation. Acutely aware of the dangers to which the English are now exposed as a consequence of successive performances of flawed government, Gloucester views this alliance as a definitive and nullifying act against the long-cherished policy of national growth through military conquest. Thus, if the arrival of this new queen, along with that of the returning native forces, signals a key moment in the dissolution of Henry V's political achievement, it also points to an equally painful realisation that Henry and his aristocratic company have fallen prey to the consolations of amnesia. Given this state of affairs, Gloucester is unsurprisingly relentless in unleashing verbal violence upon an already dejected court: 
O peers of England, shameful is this league,

Fatal this marriage, cancelling your fame,

Blotting your names from books of memory,

[...] Undoing all, as all had never been!

(I.i.94-6, 99)

Gloucester's interventions at this juncture in the dramatic narrative serve to chart for the audience the grave shortcomings of English governance in recent memory and the most limited competencies of a naïve and unremarkable king who has sought to disguise his shortcomings with extravagant ceremony, a ploy which is, in fact, exploited by a goodly number of Shakespearean monarchs. Unsurprisingly, it takes just a short time for the realm to rupture into warring factions led by the ruthless magnates at Henry's court. Nonetheless, interestingly, the recourse to violence and adversarial politics makes little difference to the investment of those on-stage in retrospection. As England begins to splinter under the inordinate pressures of Yorkist and Lancastrian ambitions, the resources of memory are seen again and again to proffer some kind of redemption from or sentence upon the bloodthirsty transactions of the present. These resources become precious, indeed at points, the only mode of interpretative energy exerted in this imploding political culture in order to resist the commonplace butchery which has now come to characterise everyday life in society.

\section{The call to arms}

In a dedicatory verse to Barnabe Rich's Allarme to England (1578), the prolific writer Thomas Churchyard vigorously asserts for Elizabethan readers that peacetime infects the body of the nation "moer liek a swellinge soer, thatt festers sowndest mynd / and so bursts owtt in byells". And so, as a consequence, there is little option but to welcome the prospect of arms: "lett peace gyue place to warre". 5 During the opening years of James VI and I's reign in England, Rich himself argued that war remained uppermost in everyone's mind: "Nothing

\footnotetext{
${ }^{5}$ Thomas Churchyard, "Gentleman, in commendation of this worke", in Barnabe Rich, Allarme to England, foreshewing what perilles are procured, where the people liue without regarde of Martiall lawe. With a short discourse conteyning the decay of warlike discipline, conuenient to be perused by Gentlemen, such as are desirous by seruice, to seeke their owne deserued prayse, and the preseruation of their countrey, 1578 , sig. * 2 r.
} 
waxeth young in this world but warre". ${ }^{6}$ However, after having tasted the fruits of peace for over a decade in Jacobean England, Rich remained convinced that peace contaminated the minds and bodies of everyone under its power: indeed "it infeebleth the mindes of young men". This perceived state of political torpor even corrupted the fundamental conditions of existence, polluting all powers of human intercourse: "Hermaphrodites, halfe-men, halfe harlots, it effeminates their minds, and nuseleth them vp in all kinde of Folly". ${ }^{7}$ And, it appears, a great number of those who inhabit Shakespeare's dramatic environments show themselves to be similarly minded. Thus, in Richard III and even Troilus et Cressida, for example, the reprieve from war comes little by little to signify not only a loss of cultural direction, but a painful interrogation of the ethical commitments of those onstage.

Interestingly, however, Shakespeare's histories do present us with figures such as Lady Percy in 1 Henry $I V$ who are determined not to submit to the prevailing zeitgeist of warfare. Yet, her exertions ultimately demonstrate little but her marginal status and her inevitable personal defeat in such a world. If she repeatedly attempts to challenge with unfailing eloquence the military ambitions of her husband, it is revealing that even she is unable to purge her language of the lexis of the battlefield. Hotspur's night-time catechism "Of sallies and retires, of trenches, tents / Of palisadoes, frontiers, parapets" (II.iv.45-46) is clearly deeply engraved in her consciousness and remains her only means of mental navigation through this war-torn landscape. At such moments we may be reminded that one of Elizabeth's premier subjects, Robert Devereux, Earl of Essex, was himself wholly representative of those wishing to win the attentions of the Crown in the final decades of the sixteenth century in that he was in some difficulty to find a profession other than that of soldiery in which to distinguish himself upon the national stage. Since the middle of the 1580 s when Elizabeth had sent military companies to assist England's co-religionists in the Dutch Revolt, the commitment to warfare had come increasingly to preoccupy the lives and print culture of the realm; and it was in this

\footnotetext{
${ }^{6}$ Barnabe Rich, A souldiers wishe to Britons welfare: or a discourse, fit to be read of all gentlemen and souldiers. Written by a Captaine of experience, 1604, p. 4.

7 Barnabe Rich, OPINION DIEFIED [sic]. Discouering the Jngins, Traps, and Traynes, that are set in this Age, whereby to catch Opinion, 1613, p. 27.
} 
very period that Essex submitted in his Apology (1600) "the greatnesse of her Majestie's favor must grow out of the greatnesse of her servants' merits: \& I saw no way of merit lye so open as by service in her wars". 8 If Shakespeare's plays regularly invite us to reflect upon the diversity and changing significations of the pasts which his characters inherit, in the History plays this concern is inflected under specifically martial terms. His audiences in such plays are never allowed to forget how the appetite for brutality has become an organizing principle in the lives of the communities it depicts and how any respite from its attritional regime is repeatedly understood in terms of its terrifying provisionality.

The interminable cycles of national experience governed by warring factions which these plays chronicle can only serve to remind us that the human condition itself may be locked in a continuum of competing accounts of human violence, and the dramatic process can re-enact in revealing and purposeful ways the very indeterminacy of this competition. As Paul Ricœur points out persuasively in Temps et Récit, the re-enactment of the decision-making processes underpinning the narrativisation of human experience can radically unsettle the reassuring vectors of cause and effect, and draw attention to

des possibilités oubliées, des potentialités avortées, des tentatives réprimées (une des fonctions de l'histoire à cet égard est de reconduire à ces moments du passé où l'avenir n'était pas encore décidé, où le passé était lui-même un espace d'expérience ouvert sur un horizon d'attente) $[\ldots]^{9}$

Thus, from this perspective, our encounters in the Henry VI plays with the gathering momentum of Cade's rebellion, the mental and political decay of the young Lancastrian king, or the acutely changeful nature of our relationship with Richard of Gloucester need not necessarily be governed by closure, by the eradication of cultural possibility. In the fifteenth-century England which Shakespeare summons up for his audiences, we are not only called upon to contemplate the political sins of times past, but to ponder an incomplete cultural environment in which Cade's insurrection in 2 Henry VI, Hotspur's military dynamism

\footnotetext{
${ }^{8}$ Robert Devereux, An apologie of the Earle of Essex, 1600, sig. A3v.

${ }^{9}$ Paul Ricœur, Temps et récit, tome III : 'Le Temps raconté', Paris, Seuil, 1985, p. 329.
} 
in 1 Henry IV, or Richard's superior intelligence continue to dominate the dramatic narratives for succeeding generations of eyes.

The realm of Henry VI, governed precariously by successive English warlords, and characterised by social collapse and large-scale slaughter, inevitably looks forward to Shakespeare's tragic productions in the opening years of the seventeenth century. Indeed, in direct comparison with works such as King Lear and Coriolanus, the vision of human chaos engendered in the Henry VI plays can only be articulated in terms of the futility of arms ("arms avail not now that Henry's dead", 1 Henry VI, I.i.47) and the exhaustion of language itself : "What should I say? His deeds exceed all speech" (1 Henry VI, I.i.15). In this perilous environment, Henry VI finds himself a reluctant and unimpressive player, forced at several points to confront resisting readers of his Lancastrian sovereignty. In the face of such opposition, the young monarch tries to assert the legitimacy of his rule in this bloodthirsty age with the memory that his grandfather "Henry the Fourth by conquest got the crown". York remains unpersuaded by this assertion and turns upon his failing political master with an imperious attitude of defiance. Rather than paying homage to Lancastrian lordship, York challenges such assertions of royal authority in the court and shows himself determined to close down any debate that the Crown might have a monopoly upon political violence: "Twas by rebellion against his king" (3 Henry VI, I.i.133-4). Thus, in this medievalised society of the Henry VI plays, the relentless vendettas between the titled warlords constantly accentuate the imponderable resolution of the nation's experience.

\section{Memory, history and political subjectivity}

In the Confessions, Saint Augustine celebrates the faculty of memory as a key resource with which to understand the potential of human spirituality, indeed of human subjectivity:

I come to the fields and vast palaces of memory, where are the treasuries of innumerable images of all kinds of objects brought in by sense-perception [...] Memory's huge cavern, with its mysterious, secret, and indescribable nooks and crannies, receives all these perceptions, to be recalled when needed and reconsidered [...] But where in my consciousness, Lord, do you dwell? [...] You conferred this honour on 
my memory that you should dwell in it. But the question I have to consider is, In what part of it do you dwell? ${ }^{10}$

This determination to unravel the complexities of the human condition in terms of the transactions of memory is rendered explicit in the dramatic narratives of the Henry VI plays. Here, Shakespeare returns repeatedly to demonstrate that one of the primary ways in which his political players identify themselves in the public sphere of political power-brokering is by wielding the authority of memory. Indeed, the remorseless investment in this faculty by the nation's governing elite is frequently placed in direct relation to the onset in the nation's life of political inertia: the inability of the warlords and their retainers to forget renders them all too frequently incapable of assuming political initiatives. Such characters are held hostage by the grievances of kin and clientage which they have inherited from the past and, at such moments, we may be reminded, as Jacques Le Goff has underlined, that "Trop privilégier la mémoire c'est s'immerger dans le flot indomptable du temps". ${ }^{11}$

In the sixteenth century, Michel de Montaigne shared with his readers an ever expanding range of meditations upon the command which memory might have on our attentions. His responses in this area could range from resignation and reverence to extravagant outrage, but he gave clear evidence in all his discussions of his knowledge of the cultural debates surrounding the faculty which had been unfolding since antiquity. Notably, in the Essais Montaigne indicates his willingness to interrogate the cultural données of his age and submitted provocatively in "Des Menteurs", for example, that "il se veoid par

\footnotetext{
${ }^{10}$ Augustine, Confessions, trans. Henry Chadwick, Oxford, O.U.P./World's Classics, 1998: bk. X, viii (12 \& 13), xxv (36), p. 185, 186, 200. In this context Donald J. Wilcox underlines that "By locating time in his own soul Augustine was not diminishing its significance but enlarging it, for the same memory and expectation which gave him his sense of time was also the repository of faith and hope and of his experience of God. 'Since the time I learned you, you stay in my memory and there I find you whenever I call you to mind and delight in you' (Confessions, X.xxv)." See Donald J. Wilcox, The Measure of Times Past: PreNewtonian Chronologies and the Rhetoric of Relative Time, Chicago, University of Chicago Press, 1987, p. 126. Mark Freeman also stresses that "what Augustine's work showed, in addition to the centrality of faith, was that the idea of rewriting the self, along with the interconnected conceptual triad of history, memory and narrative, might serve as a kind of central figure or pivot around which to think about human lives and human development." See Mark Freeman, Rewriting the Self: History, Memory, Narrative, London, Routledge, 1993, p. 19.

11 "Préface à l'édition française", in Jacques Le Goff, Histoire et Mémoire, Paris, Gallimard, 1998, p. 11.
} 
expérience [...] que les mémoires excellentes se joignent volontiers aux jugements débiles". ${ }^{12}$ Thus, with an effortless and characteristic exploitation of ironia, Montaigne returned his readers' attention (after showcasing his own memorial prowess) to the thorny relations between the operations of memory and those of cognition. Similarly, his younger contemporary across the Channel, the lawyer and natural philosopher Francis Bacon, returned regularly to this very question, speculating upon the status and function of the faculty in epistemological terms: "he who remembers or recollects, thinks; he who imagines, thinks; he who reasons, thinks". ${ }^{13}$ And interestingly, it is widely apparent that at the turn of the twentieth century a whole generation of theorists were continuing to focus intellectual debate upon the contribution that memory might make to changing understandings of modernity itself. Henri Bergson, for example, was at pains to highlight in Matière et Mémoire (1896) that "Ces deux actes, perception et souvenir, se pénètrent donc toujours, échangent toujours quelque chose de leurs substances par un phénomène d'endosmose". ${ }^{14}$

Nevertheless, returning to the centuries of early modernity, successive generations of humanist scholars had examined and reexamined the competing claims that memory and writing might have upon the human record of knowledge. One of the domains in which this debate was regularly rehearsed was that of historiography. In context of post-Reformation England, for example, the solemnities, obligations and acts of respect devoted to the writing, commentary, translation and reading of History could clearly operate as one of the dominant cultural interventions responding to a more general and acutely felt need to express reverence for a cultural directive which had in previous decades been reserved for pieties of Catholic worship. Indeed, more generally, we may be reminded that since Aristotle's De Memoria et Reminiscentia, at least, memory had been conceived as supplement, as the faculty which addressed itself most keenly to the human experience of absence, lack and insufficiency. Interestingly, in

12 “Des Menteurs", in Michel de Montaigne, Essais, éd. J.-V. Leclerc, tome I, Paris, Garnier, 1878, I, IX, p. 25-6.

13 Francis Bacon, The Works of Francis Bacon, eds. J. Spedding, R. L. Ellis and D. D. Heath, 14 vols., London, Longman et al., 1857-74: IV, 325.

${ }^{14}$ Henri Bergson, Matière et Mémoire. Essai sur la relation du corps à l'esprit, Paris, Presses Universitaires de France, 1965, p. 38. 
more recent times, Pierre Nora has conceived of an acrimonious relation between the narratives of History and Memory:

L'histoire est la délégitimation du Passé vécu [...] Car notre rapport au passé, tel du moins qu'il se déchiffre à travers les productions historiques les plus significatives, est tout autre que celui qu'on attend d'une mémoire. Non plus une continuité rétrospective, mais la mise en lumière de la discontinuité. ${ }^{15}$

However, by way of response, it might be argued that such a "continuité retrospective" has never constituted a governing pressure on received thinking regarding the grand narratives of empire and revolution, nor regarding the formation of our everyday selves. And it quickly becomes apparent that nowhere is the radical discontinuity of the human condition more eloquently expressed than in the collectively experienced trauma of warfare. Indeed, Shakespeare's characters quickly realise that their experiences of remorseless violence and profound uncertainty are the axes along which to understand national life in Henry VI's England. The young king himself submits, "my state, 'twixt Cade and York distressed, / Like to a ship that, having scaped a tempest, / Is straightway calmed and boarded with a pirate" (2 Henry VI, IV.ix.31-3). However, if this staging of fifteenth-century England, tormented by the conflicting ambitions of the Yorkists and Lancastrians, is shown to internalise the violence which Henry $\mathrm{V}$ had earlier sought to transport beyond his island's shores, his young son retains a significant dramatic function in that his commitment to view the political life of the nation as a spectator of sport offers the primary lens for audiences beyond the stage through which to understand the cultural decline of the whole body politic as a whole.

\section{Concluding thoughts : a theatre of war and memory}

The English History plays of the 1590s represent a key element of cultural performance and interrogation in the closing years of Elizabeth's reign and sustain a complex dialogue with a burgeoning market within the print culture of the time which remained obsessively interested in unpacking the aims and objectives of miltarism per se. Publications such as William Garrard's The Arte of Warre (1591), Gyles

15 “Entre Mémoire et Histoire”, in Pierre Nora, Les Lieux de Mémoire, t. I, Paris, Gallimard, 1984, p. xx, xxi. 
Clayton's The approoued order of martiall discipline (1591), Charles Gibbon's Watchword for War (1596), or Robert Barrett's The Theorike and Practicke of Modern Warres (1598) and many more clearly respond to the growing appetite as the sixteenth century drew to a close to scrutinize the technology and discipline of soldiery in a society which had no formal environment devoted to such educative purposes. Importantly, the discussion of armed combat, in direct comparison to the vast majority of learning environments in the early modern period, could not unfold without attending to the exemplarity contained within the writings of the ancients. Thus, the very commitment to fight remained a negotiation with competing recollections of inherited narratives of historic battles, legendary strategies and antique codes of conduct promoted by distant generations such as Vegetius and Frontinus. If the resources of memory were thus being deployed to secure the currency of military practice for contemporary eyes, Henri Bergson in Matière et Mémoire remains timely in his cautious reminder that this desire to connect with a founding culture in the past can only lead to provisional achievements:

Encore le passé où nous remontons [...] est-il glissant, toujours sur le point de nous échapper, comme si cette mémoire régressive était contrariée par l'autre mémoire, plus naturelle, dont le mouvement en avant nous porte à agir et à vivre. ${ }^{16}$

Nevertheless, Shakespeare's histories may be seen to exercise this power of intervention in late Elizabethan cultural debates in a highly strategic manner, recreating (rather than recounting) the civil disorders of the earlier century. Concertina-ing in creative and provocative ways the narratives inherited from his chronicle sources, these plays stretch and compress the lives and ambitions of the political players who shape these dramatisations of national life. Indeed, the very motions of selection, ellipsis and supplement to which these plays commit themselves so vigorously shadow remarkably the preferred operations of the faculty of memory itself. Moreover, as we have seen, if these dramatisations of fifteenth-century England inevitably compel audiences of whatever century to scrutinize their own cultural moment in their many and various constructions of natio, patria and gens, they nevertheless oblige us equally to attend closely to

\footnotetext{
${ }^{16}$ Henri Bergson, Matière et Mémoire, p. 49.
} 
the narratives in potentia played out on stage, the very indeterminacy of the pasts we digest and recycle for future generations.

By way of conclusion, it might be added that if Shakespeare's histories constantly send us back into the past to interrogate the organising principles of collective life in times of warfare and to remain alert to the close proximity of its performances of violence, audiences are not allowed to forget that the characters locked in the fifteenthcentury never fail to make public their illusions that they retain a cultural autonomy from and chronological difference to the past. In 1 Henry VI, for example, Sir William Lucy indulges in a deliberately histrionic rhetorical display for the assembled companies of French and English forces. When he throws back the conditions of surrender in the faces of England's adversaries, Lucy affirms that the vast distances which supposedly separate the two nations in terms of cultural priority and national destiny may even be communicated as linguistic difference: "Submission, Dauphin! 'Tis a mere French word; / We English warriors wot not what it means" (Iv.vii.54-5). In the event, Shakespeare's audiences become increasingly sceptical concerning the divides that may exist between nation and nation, sovereign and sovereign, century and century as these plays unfold.

In the Confessions, Augustine famously argued that 'my boyhood, which is no longer, lies in past time which is no longer [...] neither future nor past exists [...] The present considering the past is the memory, the present considering the present is immediate awareness, the present considering the future is expectation.'17 Ultimately, it may indeed prove that in the desire to unpick our own contemporary politics of subjectivity and violence in Shakespeare History plays, we are locked into a beguiling mise-en-abîme composed originally for the playhouses of the sixteenth century. We continue to look back to the productions of these seemingly remote institutions, as their own audiences were invited to behold the figuration of their riven society in the conflicts of previous centuries, as the plays' own characters, like Shakespeare's Henry V, are urged to 'unwind your bloody flag' to arrive at the recognition, as Augustine had counselled, that the future is also embedded in the past:

${ }^{17}$ Confessions, bk. XI, xviii (23), xx (26), respectively p. 234, 235. 
Look back into your mighty ancestors

Go, my dread lord, to your great-grandsire's tomb,

From whom you claim; invoke his warlike spirit [...]

(Henry V, I.ii.102-4)

Andrew Hiscock

Bangor University, Wales 